\title{
ENDOSCOPIC LASER LITHOTRIPSY FOR COMPLICATED BILE DUCT STONES. Is cholangioscopic guidance necessary?
}

\author{
Ralf JAKOBS ${ }^{1}$, Julio C. PEREIRA-LIMA², Aline W. SCHUCH², Lucas F. PEREIRA-LIMA², \\ Axel EICKHOFF ${ }^{1}$ and Juergen F. RIEMANN ${ }^{1}$
}

\begin{abstract}
Background - Endoscopic papillotomy is successful in more than $95 \%$ of the cases of choledocholithiasis. For patients with difficult bile duct stones not responding to mechanical lithotripsy, different methods for stone fragmentation have been developed. Aims - To compare the results of laser lithotripsy with a stone-tissue recognizing system, when guided by fluoroscopy only or by cholangioscopy. Methods - Between 1992 and 2002 we have treated 89 patients with difficult bile duct stones by endoscopic retrograde cholangiopancreatography and laser lithotripsy. Unsuccessful extracorporeal shock-wave lithotripsy and electrohydraulic were also performed before laser in 35\% and $26 \%$ of the cases, respectively. Results - Laser was effective in $79.2 \%$ of 72 patients guided by cholangioscopy and in $82.4 \%$ of 17 cases steered by fluoroscopy. The median number of impulses in the latter was 4,335 and 1,800 with the former technique. Two parameters influenced the manner of laser guidance. In cases of stones situated above a stricture, cholangioscopic control was more effective $(64.7 \%$ vs. $31.9 \%$ ). When the stones were in the distal bile duct, fluoroscopic control was more successful. Conclusion - In cases of difficult stones in the distal bile duct, laser lithotripsy under fluoroscopic control is very effective and easily performed. Cholangioscopic guidance should be recommended just in cases of intrahepatic stones or in patients with stones situated proximal to a bile duct stenosis. In these cases, cholangioscopy should be performed either endoscopically or percutaneously.
\end{abstract}

HEADINGS - Gallstones. Lithotripsy, laser. Cholecystectomy, laparoscopic. Sphincterotomy, endoscopic.

\section{INTRODUCTION}

Endoscopic retrograde cholangiopancreatography (ERCP) with concomitant endoscopic papillotomy is the standard of care for bile duct stones removal. Overall, ERCP is successful in more than $95 \%$ of cases, with short-term morbidity in less than $10 \%(11,16,17)$. When the stones are large $(\geq 2 \mathrm{~cm})$, are situated in the intrahepatic biliary tree, are proximal to a bile duct stenosis or when there is a disproportion between the size of the stone and the diameter of distal common bile duct, stone extraction with standard balloons or Dormia baskets often fails and those cases are termed difficult bile duct stones ${ }^{(20)}$. For these patients, different stone fragmentation methods have been developed, being mechanical lithotripsy the most popular ${ }^{(11,17)}$. However this method is limited by a huge stone size and, especially, by stone impaction. For these rare cases, extracorporeal shock-wave lithotripsy (ESWL), electrohydraulic (EHL) or laser lithotripsy (LISL) could be applied ${ }^{(1,2,4)}$. EHL is performed under cholangioscopic control and LISL is usually carried out under fluoroscopic guidance only. In this study, we analyze our results with a transpapillary rhodaniumlaser lithotripsy system with a stone-tissue recognizing method, that enabled us to treat difficult bile duct stones only with fluoroscopic control with the purpose of verifying if this technique is really effective without the need of cholangioscopy and which factors are associated with failure of LISL-lithotripsy controlled by fluoroscopy.

\section{METHODS}

Between 1992 and 2002, we have treated 100 consecutive patients with difficult bile duct stones with laser lithotripsy ( 89 by ERCP and 11 percutaneously). Since the percutaneous transhepatic approach is routinely performed with a cholangioscope, these 11 patients were excluded from the analysis.

In the remaining 89 cases (Table 1) an endoscopic papillotomy with mechanical lithotripsy was initially

Departments of ${ }^{1}$ Internal Medicine C, Klinikum Ludwigshafen, Ludwigshafen, Germany and ${ }^{2}$ Gastroenterology and Hepatology, Porto Alegre School of Medical Sciences (FFFCMPA), Santa Casa University Hospital, Porto Alegre, RS, Brazil.

Correspondence: Dr. Julio C. Pereira-Lima - Rua Com. Rheingantz, 910/801-90450-020 - Porto Alegre, RS, Brazil. E-mail: jpereiralima@terra.com.br 
TABLE 1. Characteristics of 89 consecutive laser treated patients with bile duct stones

\begin{tabular}{lc}
\hline Number of patients (n) & 89 \\
Age (years) & $66(27-92)$ \\
Sex & Male: 30 \\
& Female: 59 \\
Number of stones & 1 stone: 29 \\
Stone size (maximum; mm) & 2 or more stones: 60 \\
Bile duct stenosis $(\%)$ & $22(9-40)$ \\
\hline
\end{tabular}

attempted in all patients. Unsuccessful ESWL and EHL were also performed before LISL in $35 \%$ and $26 \%$ of the cases, respectively.

A xenon lamp Rhodaniun GG dye-laser (Lithognost; Care Baasel Laser-technik, Starnberg, Germany) with integrated stone-tissue recognizing system (STDS) was used for lithotripsy (wave length $594 \mathrm{~nm}$; impulse length $=2.5 \mathrm{~ms}$; maximal impulse energie $=150$ $\mathrm{mJ})$. In cases of cholangioscopic control through the transpapillary route, the laser glass fiber (core diameter $200 \mathrm{~nm}-300 \mathrm{~nm}$ ) was placed through the working channel of a babyscope (e.g., Olympus CHF BP-34, Olympus CSF-B20, Olympus Europe, Hamburg, Germany) and positioned against the stone under direct view. In the other cases, during an ERCP, the laser glass fiber was positioned at the stone under fluoroscopic guidance through a balloon catheter or a cannula. All procedures were performed under sedation with midazolan (2-10 $\mathrm{mg})$ and/or demerol (0-50 mg)

All prognostic factors were collected prospectively before the beginning of therapy and further analyzed: age, sex, bile duct diameter, stone size, position and number, liver enzyme tests, cholangioscopic or fluoroscopic control, number and power setting of impulses and presence or absence of stone fragments at the end of the session.

For statistical analysis, we used the Cochran-Armitage-trend test to determine laser employment in relationship to outcome and the chi-square test for comparison of the therapy results. The Kruskal-Wallis test was also performed, when indicated.

\section{RESULTS}

Treatment effectiveness was similar either with cholangioscopic or fluoroscopic laser guidance; stone-free patients $=79.2 \% \mathrm{vs}$ $82.4 \%$, respectively $(P=0.706)$ (Table 2 ).

In cases in which fluoroscopic steering was employed, the median number of impulses utilized was 4,335, in comparison to 1,800 impulses in cases, in which direct view guidance was used ( $P=0.005$, Kruskal-Wallis test) However, the number of impulses, which reached the stone was similar.

TABLE 2. Comparison of the stone-free rate for the transpapillary laserlithotripsy (LISL) under fluoroscopy $(\mathrm{n}=72)$ and direct cholangioscopy $(\mathrm{n}=17)$

\begin{tabular}{lccc}
\hline & $\begin{array}{l}\text { LISL transpapillary } \\
\text { fluoroscopic }(\mathrm{n}=72)\end{array}$ & $\begin{array}{c}\text { LISL transpapillary } \\
\text { cholangioscopic (n=17) }\end{array}$ & $\boldsymbol{P}^{*}$ \\
\hline $\begin{array}{l}\text { Stone-free after laser } \\
\text { lithotripsy }\end{array}$ & $79.2 \%$ & $82.4 \%$ & 0.706 \\
$\begin{array}{l}\text { Stone-free after all } \\
\text { endoscopic procedures }\end{array}$ & $94.4 \%$ & $100 \%$ & 0.458 \\
\hline
\end{tabular}

The proportion of patients who were trated by LISL under cholangioscopic control fell from $100 \%$ in the first year to $0 \%$ in the sixth year of use of the method in our Department. This trend was statistically significant over time $(P=0.001$, CochranArmitage-trend test) (Figure 1).

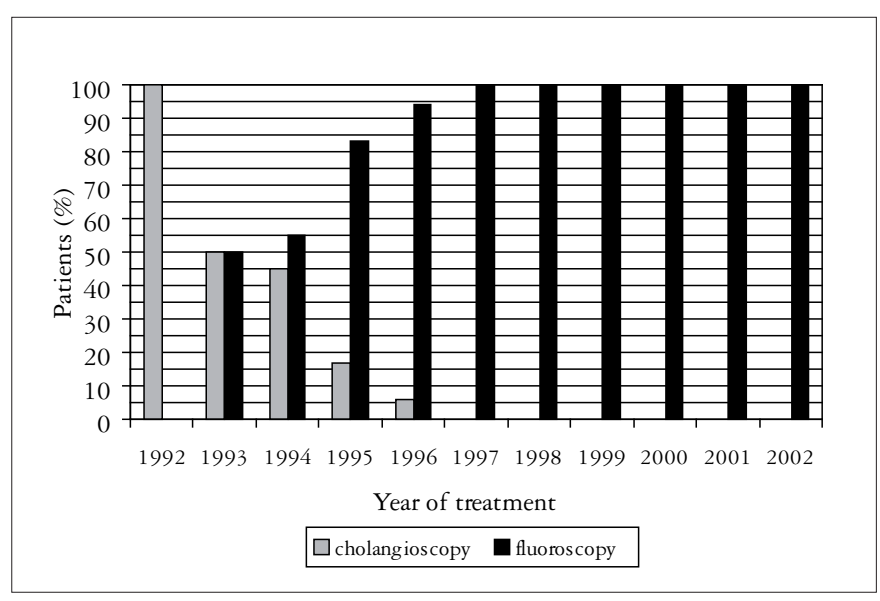

FIGURE 1. Proportion of patients that were treated under cholangioscopic or fluoroscopic control (STDS-LISL) according to the year $(P=0.001$; Cochran-Armitage-Trend-Test)

Two parameters in a statistically significant fashion influenced the manner of laser guidance. In cases with stone above a bile duct stricture, cholangioscopic control was more effective than the fluoroscopic one $(64.7 \%$ vs $31.9 \%, P=0.007)$. In cases of stones situated in the distal duct, fluoroscopic guidance was more often employed $(P=0.002)$, while in cases of intrahepatic stones, the use of cholangioscopic control was more frequent $(P=0.006)$. Other analyzed factors such as stone diameter, stone number, bile duct size had no influence in the way of laser employment or the resulting stone-free state.

There were no laser-therapy related complication with both methods of LISL steering.

\section{DISCUSSION}

The success rate of Coumarin-laser therapy without integrated stone-tissue recognizing system under fluoroscopic control for complicated bile duct stones disintegration was very low in the first studies (just 5 out of 14 stone free patients), thus cholangioscopic control was mandatory for performing this technique ${ }^{(18)}$. Nevertheless the use of transpapillary cholangioscopy is troublesome and need two experienced biliary endoscopists. In addition, when high power setting laser impulses, steered by the endoscopist, fail to reach the stone, they can produce duct injuries such as perforation and bleeding $(15,21,22)$. These same complications can be provoked by EHL. The development of STDS was a great step for LISL safety ${ }^{(6,14,22)}$. This system is based from an optical analysis of the irradiated object by the glass fibers that recognize if the targeted object is tissue or stone ${ }^{(13)}$. 
An alternative to this "optical" stone-tissue recognizing system is the piezoacoustic recognizing system, the so called FREDDY (frequency double double YAG laser), that has been used in very few Endoscopy units ${ }^{(7,9)}$.

Experimental as well as clinical data support the employment of "blind" (under fluoroscopy) LISL with $\operatorname{STDS}(5,6,7,8,9,10,13,14)$. In this series, the number of fluoroscopy-controlled LISL sessions augmented over the years and this series also shows that the effectiveness of blind LISL with STDS is comparable to cholangioscopy-guided LISL with STDS (stone-free rate = $79.2 \%$ vs $82.4 \%$ ).

In a comparison with historical series, these results are far better than the ones obtained with Coumarin-laser without $\operatorname{STDS}^{(3,18,19)}$.

Cholangioscopic control was significantly more often necessary in cases of bile duct stenosis or in patients with intrahepatic stones. This mirrors the clinical problem that these anatomical situations impose, since it is very difficult to place a catheter at the stone in these locations. Moreover, the use of a especiallydeveloped steerable catheter for these circumstances showed to be few useful in clinical practice ${ }^{(12)}$.

In cases in which the stone mass is in the distal choledochus, the employment of the "blind" technique is possible in almost all cases. This confirms the initial experience of LISL with STDS, that was reported in small series by different groups ${ }^{(18,19)}$.

A similar influence of stone location was also described for EHL, being cholangioscopic control mandatory for proximal stones and less useful in the distal bile duct ${ }^{(1)}$. The main reason for this is the sharp angulation of the distal (pre-papillary) choledochus, making often unfeasible to target the center of the stone, which is usually reached tangentially.

In this series there was a need for significant more full energy impulses by cholangioscopy with stone contact $(4,335$ vs 2323 ) in cases of fluoroscopic guidance than in the ones with cholangioscopic guidance. However, the meeting rate (percentage of impulses with full energy that was applied to the stone) was comparably high $(74 \%$ vs $75 \%)$. ELL et al. ${ }^{(4)}$ even report a need for a higher meeting rate in cases of radiological steering. In that study, patients in whom fluoroscopic control was employed, received significantly more laser impulses than patients submitted to cholangioscopic control $(2,340$ vs 1,611$)$, although the meeting rate was similar in about $89 \%$. In a study by NEUHAUS et al. ${ }^{(14)}$, there was a need for a mean of 5,320 impulses in 18 patients with a meeting rate of $74 \%$. Cholangioscopy was used to guide LISL therapy in 13 of the 18 cases $^{(14)}$. Another series of 60 patients also demonstrated that when LISL is performed by means of transpapillary cholangioscopy, there is a need for a lesser number of laser impulses than when it is performed "blindly" (1,540 vs 2,017 impulses, $P<0.05)^{(8)}$. However, it must be emphasized that a lesser number of laser impulses does not mean greater safety to the patient, nor a higher procedure efficacy, since the meeting rate with both forms of laser steering is similar as well as the stone free end result.

The two dimensional guidance provided by the fluoroscopic control provokes a higher number of laser impulses at stones of comparable size, due to the considerable amount of laser impulses liberated when the fiber contacts the stone tangentially. Thus these laser impulses provides fragmentation of irrelevant parts of the stone, i.e., its periphery. On the other hand, the cholangioscopic control allows the placement of the laser fiber in the core of the stone. However, the end results of both methods are similar making the poorly available and overtasking cholangioscopy dismissable.

In summary, in cases of difficult stones in the distal bile duct, laser lithotripsy with STDS under fluoroscopic control is very effective and easily performed. Cholangioscopic guidance should be recommended just in cases of intrahepatic stones or in patients with stones situated proximal to a bile duct stenosis. In these cases, cholangioscopy should be performed either endoscopically or percutaneously.

Jakobs R, Pereira-Lima JC, Schuch AW, Pereira-Lima LF, Eickhoff A, Riemann JF. Litotripsia endoscópica a laser para cálculos difíceis de via biliar. A colangioscopia é necessária? Arq Gastroenterol. 2007;44(2):137-40.

RESUMO - Racional - A papilotomia endoscópica é efetiva em mais de $95 \%$ dos casos de coledocolitíase . Para pacientes com cálculos de difícil extração (gigantes ou proximais a uma estenose), que não respondem à litotripsia mecânica, diferentes métodos de fragmentação foram desenvolvidos. Objetivo - Comparar os resultados da litotripsia à laser com um sistema de reconhecimento cálculo-tecido, quando guiada por fluoroscopia somente ou por colangioscopia. Métodos - Entre 1992 e 2002 foram tratados 89 pacientes com cálculos biliares de difícil extração pela colangiopancreatografia endoscópica retrógrada e litotripsia à laser. Litotripsia extracorpórea e eletro-hidráulica sem sucesso foram executados antes do laser em $35 \%$ e $26 \%$ dos casos, respectivamente. Resultados - O laser foi efetivo em 79,2\% dos 72 pacientes guiados por colangioscopia e, em 82,4\% dos 17 casos guiados por fluoroscopia. A média de impulsos do último foi de 4335 e da primeira técnica de 1 800. Dois parâmetros influenciaram o modo de orientação da litotripsia à laser. Nos casos de cálculos situados proximais a uma estenose, o controle colangioscópico foi mais efetivo (64,7\% vs 31,9\%). Quando os cálculos estavam na via biliar distal, o controle fluoroscópico era mais efetivo. Conclusão - Nos casos de cálculos biliares de difícil extração na via biliar distal, litotripsia à laser com controle fluoroscópico é muito efetiva e de fácil execução. A orientação colangioscópica deve ser recomendada somente nos casos de cálculos intra-hepáticos ou em pacientes com cálculos situados proximamente a uma estenose de via biliar. Nesses casos, colangioscopia pode ser executada tanto por via endoscópica quanto percutânea.

DESCRITORES - Cálculos biliares. Litotripsia a laser. Colecistectomia laparoscópica. Esfinterotomia endoscópica. 


\section{REFERENCES}

1. Adamek HE, Maier M, Jakobs R, Kohler B, Riemann JF. Management of retained bile duct stones: a prospective open trial comparing extracorporeal and intracorporeal lithotrispsy. Gastrointest Endosc. 1996;44:40-7.

2. Binmoeller KF, Bruckner M, Thonke F, Soehendra N. Treatment of difficult bile duct stones using mechanical, electrohydraulic and extracorporeal shock wave lithotripsy. Endoscopy. 1993;25:201-6.

3. Cotton PB, Kozarek RA, Schapiro RH, Nishioka NS, Kelsey PB, Ball TJ, Putnam WS, Barkun A, Weinerth J. Endoscopic laser lithotripsy of large bile duct stones. Gastroenterology. 1990;99:1128-33.

4. Ell C, Hochberger J, Muller D, Zirngibl H, Giedl J, Lux G, Demling L. Laser lithotripsy of gallstone by means of a pulsed neodymium-YAG laser - in vitro and animal experiments. Endoscopy. 1986;18:92-4.

5. Ell C, Wondrazek F, Frank F, Hochberger J, Lux G, Demling L. Laser-induced schockwave lithotripsy of gallstones. Endoscopy. 1986;18:95-6.

6. Ell C, Hochberger J, May A, Fleig WE, Bauer R, Mendez L, Hahn EG. Laser lithotripsy of difficult bile duct stones by means of a rhodamine-6G laser and an integrated automatic stone-tissue detection system. Gastrointest Endosc. 1993;39:755-62.

7. Hochberger J, Bayer J, Maiss J, Tex S, Hahn EG. Clinical results with a new frequencydoubled, double pulse Nd:YAG laser (FREDDY) for lithotripsy in complicated choledocholithiasis. Biomed Tech (Berl). 1998;43(Suppl):172a.

8. Hochberger J, Bayer J, May A, Mühldorfer S, Maiss J, Hahn EG, Ell C. Laser lithotripsy of difficult bile duct stones: results in 60 patients using rhodamine $6 \mathrm{G}$ dye laser with optical stone tissue detection system. Gut. 1998;43:823-9.

9. Hochberger J, Tex S, Bayer J, Stein R, Tschepe J, Hahn EG. Basic studies of piezoacoustic stone-tissue recognition system for laser lithotripsy of gallstones. Biomed Tech (Berl). 1997;42(Suppl):331a.

10. Jakobs R, Maier M, Kohler B, Benz C, Riemann JF. Peroral laser lithotripsy of difficult intrahepatic and extrahepatic bile duct stones. Laser effectiveness using an automatic stone-tissue-detection system. Am J Gastroenterol. 1996;91:468-73.

11. Jakobs R, Pereira-Lima JC, Maier M, Kohler B, Benz C, Adamek, HE, Riemann JF. Litotripsia endoscópica à laser em cálculos difíceis não responsivos à litotripsia extracorpórea por ondas de choque. Arq Gastroenterol. 1996;33:145-50.
12. Jakobs R, Riemann JF. A new steerable catheter for improving the efficiency of fluoroscopy-guided laser lithotripsy. Endoscopy. 1996;28:466.

13. Muschter R, Thomas S. Laserlithotripsy by dye laser with optical feedback-system. J Endourology. 1990;4:47a.

14. Neuhaus H, Hoffmann W, Gottlieb K, Classen M. Endoscopic lithotripsy of bile duct stones using a new laser with an automatic stone recognition system. Gastrointest Endosc. 1994;40:708-15.

15. Nishioka NS, Kelsey PB, Kibbi AG, Delmonico F, Parrish JA, Anderson RR. Laser lithotripsy: animal studies of safety and efficacy. Lasers Surg Med. 1988;8:357-62.

16. Pereira-Lima JC, Jakobs R, Winter UH, Benz C, Martin WR, Adamek HE, Riemann JF. Long-term results ( 7 to 10 years) of endoscopic papillotomy for cholecholithiasis Multivariate analysis of prognostic factors for the recurrence of biliary symptoms. Gastrointest Endosc. 1998;48:457-64

17. Pereira-Lima JC, Rynkowski CB, Rhoden EL. Endoscopic treatment of choledocholithiasis in the era of laparoscopic cholecystectomy: prospective analysis of 386 patients. Hepatogastroenterology. 2001;48:1271-4.

18. Ponchon T, Gagnon P, Valette PJ, Henry L, Chavaillon A, Thieulin F. Pulsed dye laser lithotripsy of bile duct stones. Gastroenterology. 1991;100:1730-6.

19. Prat F, Fritsch J, Choury AD, Frouge C, Marteau V, Etienne JP. Laser lithotripsy of difficult biliary stones. Gastrointest Endosc. 1994;40:290-5.

20. Shah SK, Mutignani M, Costamagna G. Therapeutic biliary endoscopy. Endoscopy. 2002;34:43-53

21. Sonden A, Svensson B, Roman N, Ostmark H, Brismar B, Palmblad J, Kjellstrom BT. Laser-induced shock wave endothelial cell injury. Lasers Surg Med. 2000;26:364-75.

22. Thomas S, Engelhardt R, Meyer W, Pensel J. Evaluation of optical feedback for preventing tissue damage in dye laser lithotripsy. Investigative Urology. $1989 ; 3: 262-70$. 